\title{
A Review on Chemical and Mechanical Properties of Natural Fiber Reinforced Polymer Composites
}

\author{
K. SRINIVAS ${ }^{1}$, A. LAKSHUMU NAIDU ${ }^{2 *}$ and M. V. A. RAJU \\ BAHUBALENDRUNI ${ }^{3}$
}

${ }^{1}$ Scholar, Department of Mechanical Engg, GMRIT, Rajam, Andhra Pradesh, India

${ }^{2,3}$ Assistant Professor, Department of Mechanical Engg, GMRIT, Rajam, India.

(Received on November 12, 2016, Revised on February 22, 2017)

\begin{abstract}
This review paper examines the chemical and mechanical properties of natural fiber reinforced polymer bonded composites and the processing techniques are compared for the reinforced composite materials. The chemical and mechanical properties of the different natural fibers composites were compared. Present days natural fibers are attracting many scholars and researchers due to its cost and largely available in nature also processing of these fibers is not hard in comparison to the conventional fiber's production. Also, Environmental awareness and a growing concern with the greenhouse effect have triggered the construction, automotive, and packing industries to watch out for ecofriendly materials that can replace conventional synthetic polymeric fiber's. Natural fibers seem to be a good alternate because they are readily available in fibrous form and can be extracted from herb leaves at very low costs. By these reasons the natural fibers are trusted over the regular fibers.
\end{abstract}

Keywords: Reinforced Polymer Composites, Mechanical Properties, Chemical Properties, Processing Techniques

\section{Introduction}

Fibres area class of hair-like material that are persistent fibers or exclusively unmistakable prolonged pieces, like bits of string. In a composite, the fibers, held together with the matrix resin, contributes high tensile strength, boosting properties in the final part such as strength and stiffness, while minimizing weight. Fibers are two types one is synthetic fibres and another one is natural fibers. Synthetic fibers are a man-made fiber these fibers are created by extruding fibers building materials through spinnerets into air and water, developing a thread. Before man-made fibers were developed, manufactured fibers were made from polymers obtained from petrochemicals. Natural fibers are manufactured or produced from the plants and animal's hair. Interest in natural fiber composites is growing for many reasons including their potential to replace synthetic fiber recognized plastics at lower cost with improved sustainability $[1,3,4]$.

Fibers are in the accumulation of polymer cast composites which consists of a polymer thermoplastic or thermosetting reinforced by fiber. In the polymer matrix composite, we have three types they are fiber reinforced composites, particle reinforced composites, structural composites.

In fiber reinforced composites, Fibre-reinforced plastic (FRP) is a composite material made of a polymer matrix reinforced with fibres. The fibres are usually glass, carbon, aramid, or basalt. Rarely, other fibres such as paper or wood or 
asbestos have been used. In particle, reinforced polymer composites the polymer matrix reinforced with the particulates. The particulates are usually silica, red mud, $\mathrm{Al}_{2} \mathrm{O}_{3}$, Sic etc. particle reinforcing in composites is a less effective means strengthening than fiber reinforcement. Structural composite is a material made from two or more constituent materials with significantly different physical or chemical properties. Natural fibres as an alternative reinforcement in polymer composites have attracted the attention of many researchers and scientists due to their advantages over conventional glass and carbon fibres. In general, fiber reinforced plastics are made by using synthetic fibers like glass, carbon, Kevlar, etc. and hence they are called as Synthetic Fiber Reinforced Plastics (SFRP). Though they have several advantages like high strength, stiffness, fatigue life and wear resistance, they also have disadvantages like high density, high cost, poor recycling and biodegradable properties. In order to overcome these disadvantages, natural fibers taken from plants and animals are being used as reinforcements in recent few years as an alternative to synthetic fibers. Composites made by using natural reinforcements are called as Natural Fiber Reinforced Plastics (NFRP). Bio-fibers like jute, sisal, vetiver, hemp, bamboo, etc. are abundantly available at a reasonable cost. These natural fibers when used as reinforcements in composites provide very good mechanical properties and they are free from environmental hazards. The research in the field of bio-fibers made huge changes to make it superior to commercially available synthetic fibers. $[2,3,5]$ Natural fibers are broadly classified into three types they are

\subsection{Plant Fibers}

Plant fibers are for a lot of allotment comprises of cellulose: illustrations cotton, flax, jute, ramie, sisal and hemp. Cellulose fibers are activated as an allotment of the accomplish of cardboard and material. The allocation of these fibers is as demography after: Berry fibers are the fibers access from the berry case and berry e.g. kapok and cotton. Leaf fibers are the fibers get from the leaves e.g. agave and sisal. Derma fibers are the fibers are get from the derma encompassing the axis of the plant.

\subsection{Animal Fibers}

Animal fibers for a lot of allotment comprises of proteins; illustrations mohair, fleece, silk, alpaca. Animal hairs are the fibers got from animals e.g. horse hair, Sheep's fleece, goat hair, alpaca hair, and so on. Silk fibers are the fibers aggregate from broiled discharge of awful crawlies throughout the time of address of covers.

\subsection{Mineral Fibers}

Mineral fibers are the commonly happening fiber or hardly adapted fibers access from minerals. It has altered classifications they are taking after: Asbestos is the capital frequently accident mineral fiber. The Variations in mineral fibers are the anthophyllite, amphiboles and serpentine. The Ceramic fibers are aluminum oxide, glass fibers, boron carbide and silicon carbide. Metal fibers absorb aluminum's fibers.

\section{Manufacturing Methods for Natural Fiber Composites}

Fiber reinforced plastics have been fabricated by several methods depending upon the shape of component to be manufactured. All those methods fall under a principle called 
polymerization. Polymerization is the process of joining large number of synthetic molecules together to form a rigid structure. The following are some important manufacturing process as provided in Table 1.

Table 1: Processing Techniques for Polymer Composites.

\begin{tabular}{|c|c|c|}
\hline $\begin{array}{c}\text { S. } \\
\text { No. }\end{array}$ & Technique & Type of Polymer Composite Processed/Manufactured \\
\hline \multirow{5}{*}{1} & \multirow{5}{*}{ Hand layup } & Bi-directional Jute Fiber Epoxy Composites [11] \\
\hline & & Sisal-Jute-Glass Fiber Reinforced Polyester Composites [12] \\
\hline & & Hybrid Glass Fiber- Sisal/Jute Reinforced Epoxy Composites [14] \\
\hline & & Banana Fiber Reinforced Polymer Composites [40] \\
\hline & & Calotropis Gigentea Fruit Fiber Reinforced Polyester Composites [45] \\
\hline \multirow{5}{*}{2} & \multirow{5}{*}{ Spray layup } & Sisal and Jute Fiber Composites [35] \\
\hline & & PLA-Based Green Composites [36] \\
\hline & & Coconut Sheath Fiber Reinforced Epoxy Composites [38] \\
\hline & & Nano Silicon Dioxide And Different Flax Structures [25, 39] \\
\hline & & $\begin{array}{l}\text { Development Of A Kraft Paper Box Lined With Thermal-Insulating Materials By } \\
\text { Utilizing Natural Wastes [53] }\end{array}$ \\
\hline \multirow{5}{*}{3} & \multirow{5}{*}{$\begin{array}{l}\text { Compression } \\
\text { moulding }\end{array}$} & Short Natural-Fibre Reinforced Polyethylene And Natural Rubber Composites [9] \\
\hline & & Jute Fiber Reinforced Composites with Polyester and Epoxy Resin Matrices [13] \\
\hline & & Banana/Sisal Reinforced Hybrid Composites [12] \\
\hline & & Natural Fibres As Reinforcement In Polylactic Acid (PLA) Composites [34] \\
\hline & & Sugarcane Bagasse Fibers Reinforced Polypropylene Composites [42] \\
\hline \multirow{5}{*}{4} & \multirow{5}{*}{$\begin{array}{l}\text { Filament } \\
\text { winding }\end{array}$} & $\begin{array}{l}\text { Cellulose Aceto-Butyrate (CAB) And Natural Rubber (NR) Reinforced With } \\
\text { Renewable Polymer Matrices. [44] }\end{array}$ \\
\hline & & Ramie Fiber Yarn Reinforced Composites [49] \\
\hline & & Jute Yarn-Biopol Composites [51] \\
\hline & & $\begin{array}{l}\text { A Multi-Component Fiber-Reinforced PHEMA-Based Hydrogel/HAPEXTM } \\
\text { Device For Customized Intervertebral Disc Prosthesis [52] }\end{array}$ \\
\hline & & $\begin{array}{l}\text { Natural Fiber-Based Reinforcements In Epoxy Composites Processed By Filament } \\
\text { Winding [54] }\end{array}$ \\
\hline \multirow{5}{*}{5} & \multirow{5}{*}{$\begin{array}{l}\text { Injection } \\
\text { winding }\end{array}$} & Woven Sisal Fibers And Natural Rubber Modified Epoxy Resin [16, 24] \\
\hline & & Bamboo-Glass Fiber Reinforced Polymer Matrix Hybrid Composites [37] \\
\hline & & Vetiver-Polypropylene Composites [41] \\
\hline & & Sugarcane Bagasse Fibers Reinforced Polypropylene Composites [42] \\
\hline & & Polypropylene Reinforced Palm Fibers Composites $[26,43]$ \\
\hline
\end{tabular}

\subsection{Hand Layup}

Hand layup is a moulding approach wherein fiber reinforcements are positioned by way of hand then polymer resin is poured at the fiber reinforcement. Second layer of the fiber reinforcements are located on the polymer resin surface and a roller is moved with a little strain on reinforced fiber to avoid the air between the layers [22, 23]. This process is repeated for every polymer resin and fiber till the appropriate layers are stacked. This kept under a pressure at room temperature around 24-48 hrs. This process is suitable for lower volume. Resins need to be low in viscosity to be workable by hand this reduces the mechanical properties of the material due to the need for high diluent/styrene levels. This process is suitable for lower volume. This gives good surface finish in on side only. It has more flexibility in material design. This process take more cycle for producing the material. $[11,40]$

\subsection{Spray Layup}

Spray layup is also one of the hand mounding technique which is actually extension of hand layup method. In this method, a spray gun is used to spray pressurized resin and 
reinforcement that is within the shape of chopped fibers. Matrix material and reinforcement can be sprayed concurrently or simultaneously one after one. A roller is rolled with a little strain over the sprayed surface to remove the air trapped into the layups. After spraying upto the required thickness curing process is done at the room temperature after this process the material is taken out from the mould. In this method, also low viscosity resins are used due to these mechanical properties are effected. This process is suitable for lower volume. This gives good surface finish in on side only. Lower cost for producing the material $[2,10]$.

\subsection{Compression Moulding}

Compression moulding is usually used for thermoplastic matrices with unfastened chopped fiber or mats of short or long fiber either randomly oriented or aligned, however can also be used with thermoset matrices. The fibers are commonly stacked alternately with thermoplastic matrix sheets earlier than stress and warmth are implemented. Compression molding is a technique of molding wherein the molding material, generally preheated, is first located in an open, heated mildew hollow space [27, 28].

\subsection{Filament Winding}

Filament winding is the manufacturing process which is mainly produces the open or closed end structures. The system entails winding filaments underneath tension over a rotating mandrel. The mandrel rotates around the spindle (Axis 1 or X: Spindle) even as a shipping eye on a carriage (Axis 2 or Y: Horizontal) traverses horizontally in step with the axis of the rotating mandrel, laying down fibers inside the preferred sample or perspective. This process is limited to convex shapes only. Low viscosity resins typically want to be used with their attendant decrease mechanical and health and safety properties [29].

\subsection{Injection Moulding}

Material granules for the element is fed through a hopper into a heated barrel, melted using heater bands and the frictional movement of a reciprocating screw barrel. The plastic is then injection through a nozzle right into a mold hollow space in which it cools and hardens to the configuration of the cavity. The mildew tool is set up on a moveable platen - when the part has solidified, the platen opens and the component is ejected out the use of ejector pins. This process give a good surface finish. This is suitable for higher volumes. This process gives lower tensile strength than most thermoset systems [50].

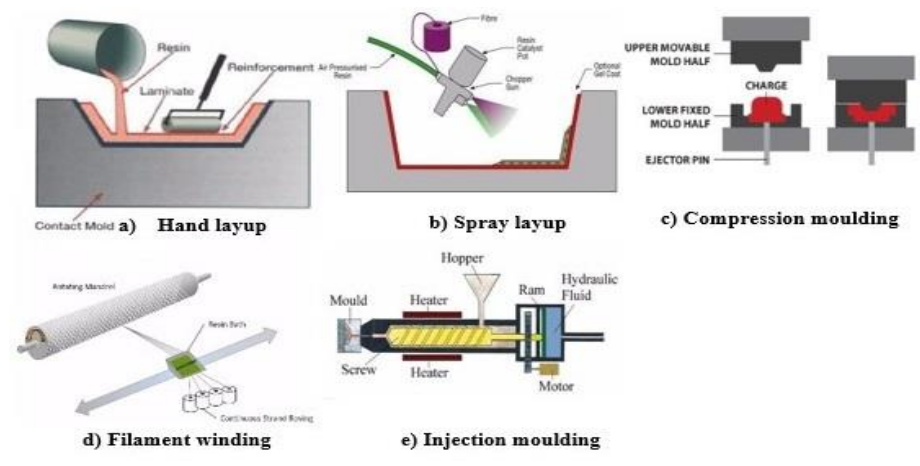

Figure 1: Types of Manufacturing Process. 


\section{Chemical Properties of Fiber Reinforced Polymer Composites}

A chemical property is a characteristic or behaviour of a substance that could be discovered when it undergoes a chemical alternate or response. Chemical homes are visible either during or following a response, considering the fact that the association of atoms inside a pattern ought to be disrupted for the property to be investigated. That is one-of-a-kind from a bodily property, which is a attribute which may be determined and measured without changing the chemical identity of a specimen. Within the average fibers, we've got the cellulose, hemicellulose, lignin are the principal chemical properties. In one of the crucial ordinary fiber has the pectin, waxes and ash in very much less number. Cellulose fibers market has been witnessing strong progress over the past few years due to growing demand from cloth industry. Developing environmental pleasant and skin friendly.

Cellulose is an important structural component of the natural fibers. It is the most abundant organic polymer on the earth. Cellulose has no taste, is odourless. Hemicellulose is a mixture of several plant polysaccharides, of smaller molecular weight than cellulose. Hemicelluloses are embedded in the cell walls of plants. Lignin is a class of complex organic polymers that form important structural materials in the support tissues of vascular plants and some algae. Lignin's are particularly important in the formation of cell walls, especially in wood and bark, because they lend rigidity and do not rot easily. Cellulose, hemi cellulose and lignin percentage is varying for different materials they are tabulated below

Table 2: Chemical Properties of Natural Fibers.

\begin{tabular}{|c|l|c|c|c|c|}
\hline $\begin{array}{c}\text { S. } \\
\text { No }\end{array}$ & $\begin{array}{c}\text { Name of } \\
\text { fiber }\end{array}$ & Cellulose (wt \%) & Hemi cellulose (wt \%) & Lignin (wt \%) & Reference \\
\hline 1 & Jute & $59-71.5$ & $13.6-20.4$ & $11.8-13$ & 7 \\
\hline 2 & Sisal & 78 & 25.7 & 12.1 & 17 \\
\hline 3 & Banana & $62-64$ & 19 & 5 & 15 \\
\hline 4 & Bamboo & $26-65$ & 30 & $5-31$ & 7 \\
\hline 5 & Flax & 71 & $18.6-21.6$ & 2.2 & 5 \\
\hline 6 & Kenaf & $45-57$ & $8-13$ & 21.5 & 10 \\
\hline 7 & Coir & 37 & 20 & 42 & 10,6 \\
\hline 8 & Palm & $60-65$ & - & $11-29$ & 6 \\
\hline 9 & Hemp & $57-77$ & $14-22.4$ & $3.7-13$ & 5 \\
\hline 10 & Curaua & $70.7-73.6$ & 9.9 & $7.5-11.1$ & 6 \\
\hline 11 & Piassava & 28.6 & 25.8 & 45 & 6 \\
\hline 12 & Ramie & $68.6-91$ & $5-16.7$ & $0.6-0.7$ & 5 \\
\hline 13 & Cotton & $82.7-90$ & 5.7 & $<2$ & 6 \\
\hline 14 & Abaca & $56-63$ & $20-25$ & $7-13$ & 6 \\
\hline 15 & Henequen & $60-77.6$ & $4-28$ & $8-13.1$ & 6 \\
\hline 16 & Alfa & 45.4 & 38.5 & 14.9 & 6 \\
\hline 17 & Betelnut & 53.20 & 32.98 & 7.20 & 18 \\
\hline
\end{tabular}

\subsection{Equipment's Used for Measurement of Chemical Properties}

In 1830's conventional method is developed for finding the cellulose percentage present in the plant tissues. By treating these materials with sodium hydroxide, potassium hydroxide, or nitric acid to extract the chemical properties like cellulose, hemi cellulose and lignin. Later some instruments are developed these are: 


\subsubsection{X-Ray Diffraction (XRD)}

The first XRD styles of cellulose fibers had been generated from wood, hemp, and bamboo samples, and even though precise structural statistics were no longer to begin with received, it become determined that the crystallites were of a rod-like form. The goal of X-ray diffraction approaches is the recording and assessment of the scattering path and depth or radiation diffracted through atom planes a hard and fast distance aside, in step with the well-known Bragg's law, $\mathrm{n} \boldsymbol{\lambda}=\mathbf{2} \boldsymbol{d} \sin \boldsymbol{\theta}$, where $\boldsymbol{\lambda}$ is the wavelength of the radiation, $\mathrm{d}$ is the distance among parallel planes, $\theta$ is the perspective of occurrence and mirrored image of X-rays with admire to the planes, and $\mathrm{n}$ is an integer. Crystallinity of flax, rutabaga, and kraft pulp nanofibers anticipated and compared with the crystallinity sample of microcrystalline cellulose [8,21].

\subsubsection{Fourier Transform Infrared Spectroscopy [FTIR]}

Fourier transform infrared spectroscopy is a way that is used to gain an infrared spectrum of absorption or emission of a strong, liquid or gasoline. An FTIR spectrometer simultaneously collects excessive spectral resolution statistics over a huge spectral range. This confers an enormous benefit over a dispersive spectrometer which measures intensity over a slender variety of wavelengths at a time.

\subsubsection{Transmission Electron Microscopy (TEM)}

Transmission electron microscopy (TEM) is a microscopy method in which a beam of electrons is transmitted via an extremely-thin specimen, interacting with the specimen because it passes through it. A photo is fashioned from the interplay of the electrons transmitted through the specimen; the photo is magnified and centered onto an imaging device, which includes a fluorescent display screen, on a layer of photographic film, or to be detected by a sensor including a fee-coupled tool. TEMs are able to imaging at a notably higher decision than mild microscopes.

\subsubsection{Atomic Force Microscopy (AFM)}

Atomic-pressure microscopy (AFM) is a very-excessive-resolution kind of scanning probe microscopy (SPM), with verified decision at the order of fractions of a nanometer, more than 1000 times better than the optical diffraction restrict.

\section{Mechanical Properties of Natural Fiber Reinforced Polymer Composites}

The mechanical properties of a material are those properties that include a response to a connected load. The mechanical properties of metals decide the scope of handiness of a material and build up the administration life that can be normal. Mechanical properties are likewise used to characterize and distinguish material. Different mechanical properties of natural fiber reinforced polymer composites are tabulated below in Table 3.

Table 3: Mechanical Properties of Natural Fiber Reinforced Polymer Composites

\begin{tabular}{|l|l|c|c|c|c|c|}
\hline $\begin{array}{l}\text { S. } \\
\text { No }\end{array}$ & $\begin{array}{c}\text { Name of } \\
\text { fiber }\end{array}$ & $\begin{array}{c}\text { Tensile strength } \\
\text { (MPa) }\end{array}$ & $\begin{array}{c}\text { Young's } \\
\text { modulus (GPa) }\end{array}$ & $\begin{array}{c}\text { Flexural } \\
\text { strength (MPa) }\end{array}$ & $\begin{array}{c}\text { Equipment's } \\
\text { used }\end{array}$ & Reference \\
\hline 1 & Abaca & $400-980$ & $6.2-20$ & - & - & 6 \\
\hline 2 & Alfa & 35 & 22 & - & - & 6 \\
\hline 3 & Bamboo & $140-800$ & $11-32$ & 32 & UTM & 7,31 \\
\hline 4 & Banana & 600 & 17.85 & 76.53 & UTM & 31,40 \\
\hline 5 & Coconut & 500 & 2.50 & 58 & UTM & 31,46 \\
\hline
\end{tabular}




\begin{tabular}{|l|l|c|c|c|c|c|}
\hline 6 & Coir & 175 & $4-6$ & 6 & UTM & 10,48 \\
\hline 7 & Cotton & 400 & 12 & 43.3 & UTM & 3,30 \\
\hline 8 & Curaua & $87-1150$ & $11.8-96$ & - & - & 6 \\
\hline 9 & Flax & $800-1500$ & $60-80$ & 165 & - & 3 \\
\hline 10 & Fique & 200 & $8-12$ & - & UTM & 30 \\
\hline 11 & Hemp & $550-900$ & 70 & - & - & 3 \\
\hline 12 & Henequen & $430-570$ & $10.1-16.3$ & 95 & UTM & $32,6,8$ \\
\hline 13 & Harakeke & 778 & 32.09 & 225 & UTM & 33 \\
\hline 14 & Jute & $320-800$ & $8-78$ & 45 & UTM & 7,13 \\
\hline 15 & Kenaf & 930 & 53 & 74 & UTM & 10,32 \\
\hline 16 & Palf & 170 & - & - & UTM & 19 \\
\hline 17 & Palm & 377 & 2.75 & 24.4 & UTM & 31,43 \\
\hline 18 & Piassava & $134-143$ & $1.07-4.59$ & - & - & 6 \\
\hline 19 & Pineapple & $413-1627$ & $34.5-84.5$ & - & UTM & 30 \\
\hline 20 & Ramie & 500 & 44 & - & - & 3 \\
\hline 21 & Sisal & $600-700$ & 38 & 288.6 & UTM & 3,47 \\
\hline 22 & Vakka & 549 & 15.85 & - & UTM & 31 \\
\hline 23 & Wool & $120-174$ & $2.3-3.4$ & - & - & 20 \\
\hline
\end{tabular}

\section{Comparative Evolution of Natural Fiber Reinforced Polymer Composites}

\subsection{Chemical Properties}

Chemical properties of the different fibers are compared and give in the Figure 2.

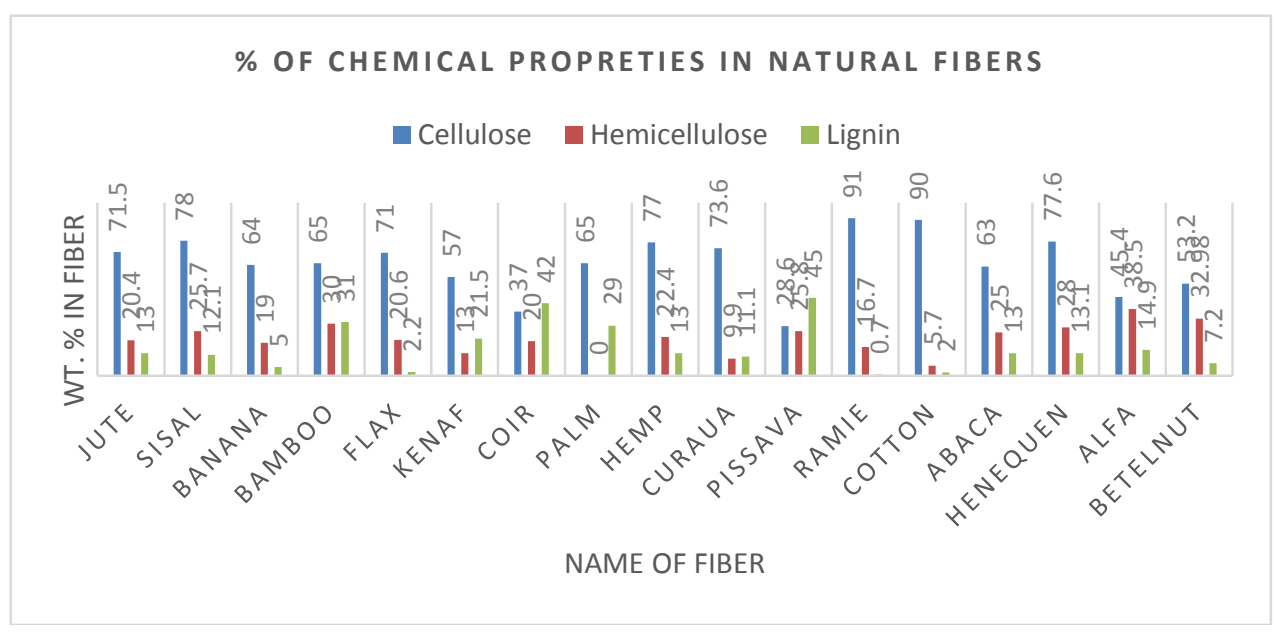

Figure 2: Chemical Properties of Natural Fibers

\section{$5.2 \quad$ Mechanical Properties}

\subsubsection{Tensile Strength}

Comparative evaluation of tensile strength of natural fiber reinforced polymer composites are evaluated and represented in Figure 3.

\subsubsection{Young's Modulus}

Comparative evolution of young's modulus of natural fiber reinforced polymer composites are evaluated and represented in Figure 4. 


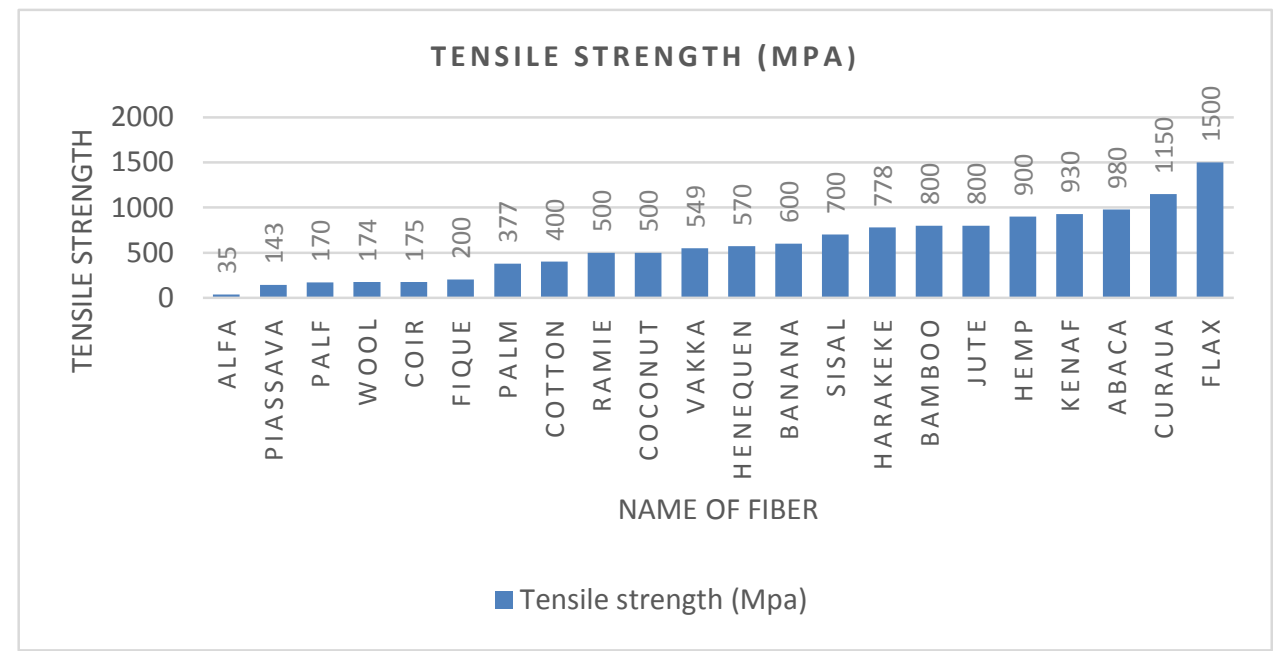

Figure 3: Tensile Properties of Natural Fiber Reinforced Composites

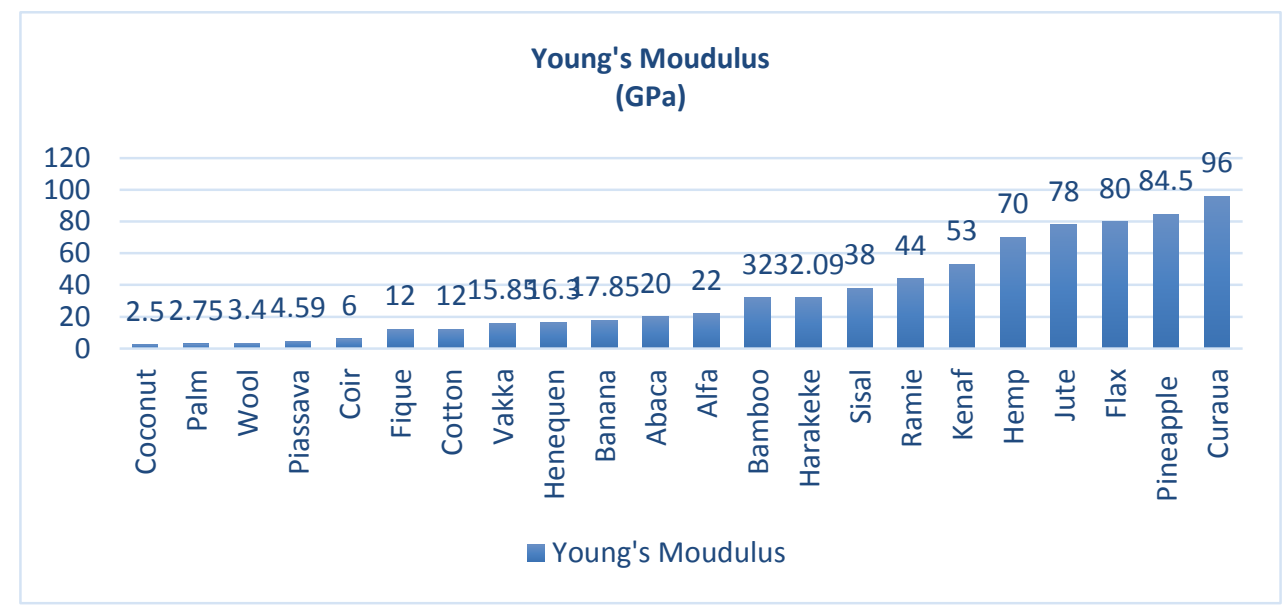

Figure 4: Young's Modulus of Natural Fiber Reinforced Polymer Composites

\subsubsection{Flexural Strength}

Comparative evolution of flexural strength of natural fiber reinforce polymer composites are evaluated and represented in Figure 5.

\section{Conclusions}

Tensile strength of the natural fibers is low compared to the synthetic fibers. The strength of the fiber depended on the fiber loading. Some of the natural fibers are close to the synthetic fibers like hemp, flax, kenaf, abaca etc. 


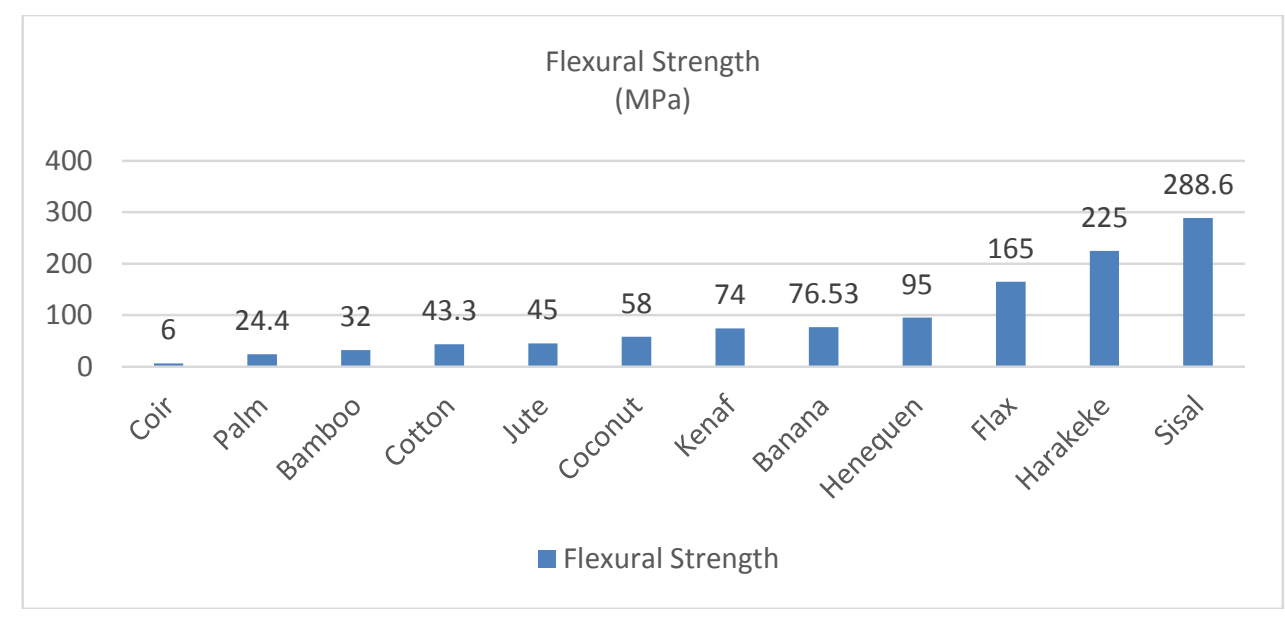

Figure 5: Flexural Properties of Natural Fiber Reinforced Polymer Composites

$>$ Young's modulus of the natural fiber is also depending on the fiber weight ratio. It is increased when the fiber weight ratio is increases up to a maximum value after that it will decreases. Some of the natural fibers have the higher young's modulus than glass fibers. Jute, hemp, flax, pineapple have the highest young's modulus value than the other natural fibers.

$>$ Flexural strength of the fiber was depending on the fiber loading. If, fiber load is increase flexural strength is increases up to optimal level then decreases.

\section{References}

[1]. Naidu. A.L., Sudarshan. B., and KH. Krishna. Study on Mechanical Behavior of Groundnut Shell Fiber Reinforced Polymer Metal Matrix Composites. International Journal of Engineering Research and Technology, Feb 2013;2(2):1-6.

[2]. Ku. H., Wang. H., Pattarachaiyakoop N., and M. Trada. A Review on the Tensile Properties of Natural Fiber Reinforced Polymer Composites. Composites Part B: Engineering, 2011 Jun 30;42(4):856-73.

[3]. Wambua. P., Ivens. J., and I. Verpoest. Natural Fibres: Can they Replace Glass in Fibre Reinforced Plastics?. Composites Science and Technology, July 2003;63(9):1259-64.

[4]. Sgriccia. N., Hawley. M.C., and M. Misra. Characterization of Natural Fiber Surfaces and Natural Fiber Composites. Composites Part A: Applied Science and Manufacturing, Oct 31, 2008;39(10):1632-7.

[5]. Naidu. A.L., Raghuveer. D., and P. Suman. Studies on Characterization and Mechanical Behavior of Banana Peel Reinforced Epoxy Composites. International Journal of Scientific \& Engineering Research, 2013;4(6):844-851.

[6]. Dittenber DB, and H.V. GangaRao. Critical Review of Recent Publications on use of Natural Composites in Infrastructure. Composites Part A: Applied Science and Manufacturing, 2012 Aug 31;43(8):1419-29.

[7]. Jayamani E, Hamdan S, Rahman MR, and M.K. Bakri. Comparative Study of Dielectric Properties of Hybrid Natural Fiber Composites. Procedia Engineering, Dec 31, 2014;97:536-44.

[8]. Naidua AL, and D.N. Raob. Studies on Characterization and Mechanical Behavior of Natural Clay. Int. Journal. of Multidisciplinary and Current research. 2013 Jul. 
[9]. Abdelmouleh M, Boufi S, Belgacem MN, and A. Dufresne. Short Natural-Fibre Reinforced Polyethylene and Natural Rubber Composites: Effect of Silane Coupling Agents and Fibres Loading. Composites science and technology, Jun 30, 2007;67(7):1627-39.

[10]. Omrani E, Menezes PL, and P.K. Rohatgi. State of the Art on Tribological Behavior of Polymer Matrix Composites Reinforced with Natural Fibers in the Green Materials World. Engineering Science and Technology, an International Journal, Jun 30, 2016;19(2):717-36.

[11]. Mishra V, and S. Biswas. Physical and Mechanical Properties of Bi-Directional Jute Fiber Epoxy Composites. Procedia engineering, Jan 1, 2013;51:561-6.

[12]. Ramesh M, Palanikumar K, and K.H. Reddy. Mechanical Property Evaluation of SisalJute-Glass Fiber Reinforced Polyester Composites. Composites Part B: Engineering, May 31, 2013;48:1-9.

[13]. Gopinath A, Kumar MS, and A. Elayaperumal. Experimental Investigations on Mechanical Properties of Jute Fiber Reinforced Composites with Polyester and Epoxy Resin Matrices. Procedia Engineering, Jan 1, 2014;97:2052-63.

[14]. Ramesh M, Palanikumar K, and K.H. Reddy. Comparative Evaluation on Properties of Hybrid Glass Fiber-Sisal/Jute Reinforced Epoxy Composites. Procedia Engineering, Jan 1, 2013;51:745-50.

[15]. Badrinath R, and T. Senthilvelan. Comparative Investigation on Mechanical Properties of Banana and Sisal Reinforced Polymer Based Composites. Procedia Materials Science, Jan 1, 2014;5:2263-72.

[16]. Srisuwan S, Prasoetsopha N, Suppakarn N, and P. Chumsamrong. The Effects of Alkalized and Silanized Woven Sisal Fibers on Mechanical Properties of Natural Rubber Modified Epoxy Resin. Energy Procedia, Jan 1, 2014;56:19-25.

[17]. Sreekumar PA, Joseph K, Unnikrishnan G, and S. Thomas. A Comparative Study on Mechanical Properties of Sisal-Leaf Fibre-Reinforced Polyester Composites Prepared by Resin Transfer ond Compression Moulding Techniques. Composites Science and Technology, Mar 31, 2007;67(3):453-61.

[18]. Jayamani E, Hamdan S, Rahman MR, and M.K. Bakri. Investigation of Fiber Surface Treatment on Mechanical, Acoustical and Thermal Properties of Betelnut Fiber Polyester Composites. Procedia Engineering, Dec 31, 2014;97:545-54.

[19]. Devi LU, Bhagawan SS, and S. Thomas. Mechanical Properties of Pineapple Leaf Fiber-Reinforced Polyester Composites. Journal of Applied Polymer Science, May 31, 1997;64(9):1739-48.

[20]. Cheung HY, Ho MP, Lau KT, Cardona F, and D. Hui. Natural Fibre-Reinforced Composites for Bioengineering and Environmental Engineering Applications. Composites Part B: Engineering, Oct 31, 2009;40(7):655-63.

[21]. Milanese AC, Cioffi MO, and H.J. Voorwald. Mechanical Behavior of Natural Fiber Composites. Procedia Engineering, Jan 1, 2011;10:2022-7.

[22]. Fiore V, Scalici T, Di Bella G, and A. Valenza. A Review on Basalt Fibre and its Composites. Composites Part B: Engineering, Jun 1, 2015;74:74-94.

[23]. Summerscales J, Virk A, and W. Hall. A Review of Bast Fibres and their Composites: Part 3-Modelling. Composites Part A: Applied Science and Manufacturing, Jan 31, 2013;44:132-9.

[24]. Hossain MR, Islam MA, Van Vuurea A, and I. Verpoest. Tensile Behavior of Environment Friendly Jute Epoxy Laminated Composite. Procedia Engineering, Jan 1, 2013;56:782-8.

[25]. Ashworth S, Rongong J, Wilson P, and J. Meredith. Mechanical and Damping Properties of Resin Transfer Moulded Jute-Carbon Hybrid Composites. Composites Part B: Engineering, Nov 15, 2016;105:60-6.

[26]. Biswas S, Shahinur S, Hasan M, and Q. Ahsan. Physical, Mechanical and Thermal Properties of Jute and Bamboo Fiber Reinforced Unidirectional Epoxy Composites. 
Procedia Engineering, Jan 1, 2015;105:933-9.

[27]. de Andrade Silva F, Chawla N, de Toledo Filho RD. Tensile Behavior of High Performance Natural (Sisal) Fibers. Composites Science and Technology, Dec 31, 2008;68(15):3438-43.

[28]. Rong MZ, Zhang MQ, Liu Y, Yang GC, and H.M. Zeng. The Effect of Fiber Treatment on the Mechanical Properties of Unidirectional Sisal-Reinforced Epoxy Composites. Composites Science and technology, Aug 31, 2001;61(10):1437-47.

[29]. Belaadi A, Bezazi A, Maache M, and F. Scarpa. Fatigue in Sisal Fiber Reinforced Polyester Composites: Hysteresis and Energy Dissipation. Procedia Engineering, Jan 1, 2014;74:325-8.

[30]. De Rosa IM, Kenny JM, Puglia D, Santulli C, and F. Sarasini. Tensile Behavior of New Zealand Flax (Phormium Tenax) Fibers. Journal of Reinforced Plastics and Composites, Dec 1, 2010;29(23):3450-4.

[31]. Rao KMM, and K.M. Rao. Extraction and Tensile Properties of Natural Fibers: Vakka, Date and Bamboo. Composite Structures, Feb 28, 2007;77(3):288-95.

[32]. Lee BH, Kim HJ, and W.R. Yu . Fabrication of Long and Discontinuous Natural Fiber Reinforced Polypropylene Biocomposites and their Mechanical Properties. Fibers and Polymers Feb 1, 2009;10(1):83-90.

[33]. Le TM, and K.L. Pickering. The Potential of Harakeke Fibre as Reinforcement in Polymer Matrix Composites Including Modelling of Long Harakeke Fibre Composite Strength. Composites Part A: Applied Science and Manufacturing, Sep 30, 2015;76:4453.

[34]. Oksman K, Skrifvars M, and J.F. Selin. Natural Fibres as Reinforcement in Polylactic Acid (PLA) Composites. Composites Science and Technology, Jul 31, 2003;63(9):131724.

[35]. Costa FH, and J.R. d'Almeida. Effect of Water Absorption on the Mechanical Properties of Sisal and Jute Fiber Composites. Polymer-Plastics Technology and Engineering, Nov 1, 1999;38(5):1081-94.

[36]. Bajpai P. K., Singh I., and J. Madaan, "Composite Materials," 2012.

[37]. Thwe MM, and K. Liao. Effects of Environmental Aging on the Mechanical Properties of Bamboo-Glass Fiber Reinforced Polymer Matrix Hybrid Composites. Composites Part A: Applied Science and Manufacturing, Jan 31, 2002;33(1):43-52.

[38]. Kumar S.S., Duraibabu D., and K. Subramanian. Studies on Mechanical, Thermal and Dynamic Mechanical Properties of Untreated (Raw) and Treated Coconut Sheath Fiber Reinforced Epoxy Composites. Materials \& Design, Jul 31, 2014;59:63-9.

[39]. S. Siengchin and R. Dangtungee, "Composite Materials," 2014.

[40]. Ramesh M, Atreya TS, Aswin US, Eashwar H, and C. Deepa. Processing and Mechanical Property Evaluation of Banana Fiber Reinforced Polymer Composites. Procedia Engineering, Dec 31, 2014;97:563-72.

[41]. Ruksakulpiwat Y, Suppakarn N, Sutapun W, and W. Thomthong. VetiverPolypropylene Composites: Physical and Mechanical Properties. Composites Part A: Applied Science and Manufacturing, Feb 28, 2007;38(2):590-601.

[42]. Luz SM, Gonçalves AR, and A.P. Del'Arco. Mechanical Behavior and Microstructural Analysis of Sugarcane Bagasse Fibers Reinforced Polypropylene Composites. Composites Part A: Applied Science and Manufacturing, Jun 30, 2007;38(6):1455-61.

[43]. Goulart SA, Oliveira TA, Teixeira A, Mileo PC, and D.R. Mulinari. Mechanical Behaviour of Polypropylene Reinforced Palm Fibers Composites. Procedia Engineering, Jan 1, 2011;10:2034-9.

[44]. Ly B, Thielemans W, Dufresne A, Chaussy D, and M.N. Belgacem. Surface Functionalization of Cellulose Fibres and their Incorporation in Renewable Polymeric Matrices. Composites Science and Technology, Dec 31, 2008;68(15):3193-201.

[45]. Babu GD, Babu KS, and P.N. Kishore. Tensile and Wear Behavior of Calotropis Gigentea Fruit Fiber Reinforced Polyester Composites. Procedia Engineering, Dec 31, 
2014;97:531-5.

[46]. Vijayakumar S, Nilavarasan T, Usharani R, and L. Karunamoorthy. Mechanical and Microstructure Characterization of Coconut Spathe Fibers and Kenaf Bast Fibers Reinforced Epoxy Polymer Matrix Composites. Procedia Materials Science, Jan 1, 2014;5:2330-7.

[47]. Gupta MK, and R.K.Srivastava. Tensile and Flexural Properties of Sisal Fibre Reinforced Epoxy Composite: A Comparison Between Unidirectional and Mat Form of Fibres. Procedia Materials Science, Jan 1, 2014;5:2434-9.

[48]. Naidu. A.L., Jagadeesh. V and MVARB. A Review on Chemical and Physical Properties of Natural Fiber Reinforced Composites, International Journal of Advanced Research in Engineering and Technology, 8(1), 2017, pp 56-68.

[49]. Ma H, Li Y, Shen Y, Xie L, and D. Wang. Effect of Linear Density and Yarn Structure on the Mechanical Properties of Ramie Fiber Yarn Reinforced Composites. Composites Part A: Applied Science and Manufacturing, Aug 31, 2016;87:98-108.

[50]. Zou Y, Reddy N, and Y. Yang. Reusing Polyester/Cotton Blend Fabrics for Composites. Composites Part B: Engineering, Jun 30, 2011;42(4):763-70.

[51]. Mohanty AK, Khan MA, Sahoo S, and G. Hinrichsen. Effect Of Chemical Modification On The Performance Of Biodegradable Jute Yarn-Biopol ${ }^{\circledR}$ Composites. Journal of Materials Science. May 1, 2000;35(10):2589-95.

[52]. Gloria A, De Santis R, Ambrosio L, Causa F, and KE.Tanner. A Multi-Component Fiber-Reinforced PHEMA-Based Hydrogel/HAPEXTM Device for Customized Intervertebral Disc Prosthesis. Journal of Biomaterials Applications, May 28, 2010.

[53]. Klinklow N, Padungkul S, Kanthong S, Patcharaphun S, and R. Techapiesancharoenkij. Development of a Kraft Paper Box Lined with Thermal-Insulating Materials by Utilizing Natural Wastes. In Key Engineering Materials 2013;545: 82-88.

[54]. Lehtiniemi P, Dufva K, Berg T, Skrifvars M, and P. Järvelä. Natural Fiber-Based Reinforcements in Epoxy Composites Processed by Filament Winding. Journal of Reinforced Plastics and Composites, Dec 2011;30(23):1947-55.

K. Srinivas is currently pursuing M.Tech in Thermal Engineering at GMR IT, Rajam and Andhra Pradesh.

A. Lakshumu Naidu is currently working as an Assistant Professor in Department of Mechanical Engineering at GMR IT, Rajam, and Andhra Pradesh and has vast teaching experience. He completed his M.Tech (Design and Manufacturing) from Centurion University of Technology and Management, Odisha, India in 2013 and B.Tech in Mechanical Engineering 2011. His research interest includes Composite Materials, Nanofluids and Biofuels. He has published two patents and has published papers also in peer-refereed journals and he is reviewer for International Journal of Engineering and Technology (IJERT) and International Journal of Engineering Research and Technology, attended many International Conference like, ICAMM-2016, ICRIET-2016, ICMSEA2016.

Dr. M V A Raju Bahubalendruni is currently working as a Sr. Assistant Professor in Department of Mechanical Engineering at GMR IT, Rajam, and Andhra Pradesh and has vast teaching and industry experience. He received his Ph. D from National Institute of Technology, Rourkela, India in 2017. His research interest includes Composite Materials, Assembly Automation. He has published two patents and has published papers also in peer-refereed journals and he is reviewer (SCI) for Assembly Automation (10), Proceedings of the Institution of Mechanical Engineers, Part B: Journal of Engineering Manufacture (10) attended many International Conferences. 